\title{
GMR
}

\section{Interleukin-6 (IL-6) -174G/C genomic polymorphism contribution to the risk of coronary artery disease in a Chinese population}

\author{
L. Mao, G.Y. Geng, W.J. Han, M.H. Zhao, L. Wu and H.L. Liu \\ Department of Cardiology, People's Hospital of Zhengzhou, Zhengzhou, \\ China \\ Corresponding author: H.L. Liu \\ E-mail: liuhengliang_1@163.com
}

Genet. Mol. Res. 15 (2): gmr.15027803

Received October 8, 2015

Accepted November 27, 2015

Published June 17, 2016

DOI http://dx.doi.org/10.4238/gmr.15027803

\begin{abstract}
To investigate the role of $I L-6$ polymorphism (-174G/C and $-572 \mathrm{C} / \mathrm{G})$ in the development of coronary artery disease (CAD), CAD patients (224) and control subjects (260) were recruited between January 2012 and December 2014. Genotyping at $I L-6-174 \mathrm{G} / \mathrm{C}$ and $-572 \mathrm{C} / \mathrm{G}$ was conducted via polymerase chain reaction coupled to restriction fragment length polymorphism. Results indicated that several disease risk factors were significantly higher in CAD patients as compared to the control subjects. These factors include hypertension $\left(\chi^{2}=20.03, \mathrm{P}<0.001\right)$, diabetes mellitus $\left(\chi^{2}=33.53, \mathrm{P}<0.001\right)$, tobacco smoking $\left(\chi^{2}=28.17, \mathrm{P}<0.001\right)$, body mass indexes $(t=$ 11.39, $\mathrm{P}<0.001)$, total cholesterol $(t=8.25, \mathrm{P}<0.001)$, low-density lipoprotein cholesterol $(t=7.24, \mathrm{P}<0.001)$, high-density lipoprotein cholesterol $(t=3.52, \mathrm{P}<0.001)$, and triglyceride $(t=6.09, \mathrm{P}<0.001)$. By unconditional logistic regression analysis, we observed that the CC genotype at $I L-6-174 \mathrm{G} / \mathrm{C}$ was had a $2.32(95 \% \mathrm{CI}=1.33-4.06)$ fold risk of developing CAD compared to the GG genotype. Moreover,
\end{abstract}


IL-6 -174G/C polymorphism was positively associated with the risk of developing $\mathrm{CAD}$ in both dominant $(\mathrm{OR}=1.63,95 \% \mathrm{CI}=1.12-2.38$; $\mathrm{P}=0.01)$ and recessive models $(\mathrm{OR}=2.18,95 \% \mathrm{CI}=1.26-3.77 ; \mathrm{P}=$ $0.001)$. However, no statistically significant association was observed between $I L-6-572 \mathrm{C} / \mathrm{G}$ polymorphism and risk of CAD. In conclusion, IL-6 -174G/C polymorphisms are associated with the pathogenesis of CAD.

Key words: Coronary artery disease; Interleukin 6; Polymorphism

\section{INTRODUCTION}

Coronary heart disease, also referred to as coronary artery disease (CAD), is the most common cardiovascular disease in both developed and developing regions (He et al., 2005; Go et al., 2014), and is related with high death rate and loss of disability-adjusted life years (Go et al., 2014). CAD is a complex and multifactor disease, and can be attributed to a variety of factors such as hypertension, hypercholesterolemia, lack of physical activities, diabetes, high body mass indexes, tobacco smoking, and intake of high fat and high calorie diet (Wilson et al., 1998), whereas only few of individuals with the risk factors of CAD eventually develop this disease. Therefore, inherited factors appear to be involved in the pathogenesis of CAD (Marenberg et al., 1994). Previous studies have demonstrated that genetic polymorphisms are associated with the risk of CAD, such as methylenetetrahydrofolate reductase (MTHFR) gene, angiotensin type 2 receptor, alcohol dehydrogenase, and acetaldehyde dehyrogenase 2 (Dhar et al., 2010; Tousoulis et al., 2010; Xu et al., 2010; Han et al., 2013).

Research has shown that inflammation is associated with the pathogenesis of CAD through promotion of atherosclerosis (Ross, 1999). Cytokines are the main mediators of the inflammatory response. The $I L-6$ gene, located at chromosome $7 \mathrm{p} 21-24$, is composed of 4 introns and 5 exons. Since single nucleotide polymorphisms of IL- 6 gene promoter may affect the expression and secretion of $I L-6$, and subsequently the altered circulating levels might result in relevant biological responses, and the $I L-6$ polymorphism has been regarded as a crucial modulator in pathogenesis of various diseases, including Alzheimer's disease, type 2 diabetes, celiac disease, chronic obstructive pulmonary disease and osteoarthritis (de Albuquerque Maranhão et al., 2015; Fernandes et al., 2015; Xie et al., 2015; Buraczynska et al., 2016; Ramos Dos Santos et al., 2016). Although several studies have shown that $I L-6$ polymorphisms could be also involved in the development of CAD, the conclusions were not consistent (Li et al., 2015; Liu et al., 2015; Wang et al., 2015; Yang et al., 2015). Here, we carried out a case-control study to evaluate the association between $I L-6-174 \mathrm{G} / \mathrm{C}$ and $-572 \mathrm{C} / \mathrm{G}$ genomic variants and CAD risk in the Chinese population.

\section{MATERIAL AND METHODS}

\section{Patients}

A hospital-based case-control design was conducted. A total of 224 CAD patients (79 females and 145 males, mean age $62.65 \pm 9.72$ years) and 260 health subjects (113 females and 147 males, mean age $56.82 \pm 9.80$ years) were selected from the Department of Cardiology, 
Henan Provincial People's Hospital, between February 2012 and January 2015. These patients were confirmed by at least two cardiologists using coronary angiography. CAD was defined as a diameter stenosis of above $70 \%$ in any main coronary arteries. Patients who had malignancies, myocardial spasms, myocardial bridges, as well as those suffering from autoimmune diseases, congenital heart diseases, or end-stage kidney or liver diseases were excluded from the study. Healthy control subjects were randomly selected from the physical examination center or the outpatient clinics at the Henan Provincial People's Hospital. These subjects were confirmed to have no history of arteriosclerotic lesions or cardiovascular diseases.

The demographic and lifestyle data of CAD patients and control subjects were selected through face to face interview using structured questionnaires, including information regarding gender, age, body mass index, tobacco smoking, alcohol drinking, diabetes, and hypertension. Clinical data obtained from medical records included information in terms of cholesterol (TC) level, low-density lipoprotein cholesterol (LDL-c) level, and high-density lipoprotein cholesterol (HDL-c) level, as well as triglyceride (TG) level.

The written consent of all participants was obtained by informing them about the details of the study and getting their approval. Study procedures carried out with permission from the Institutional Review Board of the Henan Provincial People's Hospital.

\section{Genetic analysis}

Five $\mathrm{mL}$ peripheral venous blood sample was obtained from each participant. DNA was extracted from the collected blood samples using the TIANamp Blood DNA Kit (Tiangen, Beijing, China) according to manufacturer recommendation. The genotyping for $I L-6-174 \mathrm{G} / \mathrm{C}$ and $-572 \mathrm{C} / \mathrm{G}$ polymorphic sites was determined by polymerase chain reaction (PCR) coupled to restriction fragment length polymorphism (RFLP). DNA samples were amplified using two different primer pairs specific for $I L-6-174 \mathrm{G} / \mathrm{C}$ and $-572 \mathrm{C} / \mathrm{G}$ genes. For $I L-6-572 \mathrm{C} / \mathrm{G}$, primer sequences were 5'-GGA GTC ACA CAC TCC ACC T-3' and 5'-CTG ATT GGA AAC CTT ATT AAG-3', respectively. For IL-6 -572C/G, primer sequences were 5'-GAG ACG CCT TGA AGT AAC TG-3' and 5'-GAG TTT CCT CTG ACT CCA TCG CA-3', respectively. The restriction enzymes for $I L-6-174 \mathrm{G} / \mathrm{C}$ and $-572 \mathrm{C} / \mathrm{G}$ were $H s p 92 \mathrm{II}$ and $M b i \mathrm{I}$, respectively. The PCR conditions are as follows: initial melting step of $95^{\circ} \mathrm{C}$ for $5 \mathrm{~min}$, and followed by 30 cycles of $94^{\circ} \mathrm{C}$ for $30 \mathrm{~s}, 60^{\circ} \mathrm{C}$ for $30 \mathrm{~s}$, and $72^{\circ} \mathrm{C}$ for $45 \mathrm{~s}$, and final extension was carried out for $7 \mathrm{~min}$ at $72^{\circ} \mathrm{C}$ for the two polymorphic sites. Digestion products were checked by using electrophoresis on ethidium bromide stained agarose gels.

\section{Statistical analysis}

The Fisher exact test was carried out to determine whether genotype and allele frequencies of $I L-6-174 \mathrm{G} / \mathrm{C}$ and $-572 \mathrm{C} / \mathrm{G}$ were in agreement with the Hardy-Weinberg equilibrium (HWE). An unconditional multivariate logistic model was used to evaluate the association between $I L-6$ polymorphisms and the risk of developing CAD. The results are represented by odds ratios (OR) along with their corresponding $95 \%$ confidence intervals (CIs). The most frequent genotype (GG for $I L-6-174 \mathrm{G} / \mathrm{C}$ and $\mathrm{CC}$ for) was used as reference group for $I L-6-174 \mathrm{G} / \mathrm{C}$ and $-572 \mathrm{C} / \mathrm{G}$ genes. The SPSS software version 17.0 (SPSS Inc., Chicago, IL, USA) was used for all statistical analyses. Results were considered statistically significant when the $\mathrm{P} \leq 0.05$. 


\section{RESULTS}

As compared with the control subjects, some demographic, lifestyle and clinical factors such as hypertension $\left(\chi^{2}=20.03, \mathrm{P}<0.001\right)$, diabetes mellitus $\left(\chi^{2}=33.53, \mathrm{P}<0.001\right)$, tobacco smoking $\left(\chi^{2}=28.17, \mathrm{P}<0.001\right)$, high body mass indexes $(t=11.39, \mathrm{P}<0.001)$, high TC $(t=8.25, \mathrm{P}<0.001)$, high LDL-c $(t=7.24, \mathrm{P}<0.001)$, high HDL-c $(t=3.52, \mathrm{P}<0.001)$, and high TG $(t=6.09, \mathrm{P}<0.001)$ were more prevalent in the CAD patients (Table 1$)$.

Table 1. Demographic, lifestyle and clinical characteristics of the recruited CAD patients and control subjects.

\begin{tabular}{|c|c|c|c|c|c|c|}
\hline Variables & CAD patients $(\mathrm{N}=224)$ & $\%$ & Controls $(\mathrm{N}=260)$ & $\%$ & $\chi^{2}$ test or $t$ test & P value \\
\hline Mean age, years & $62.65 \pm 9.72$ & & $56.82 \pm 9.80$ & & & \\
\hline \multicolumn{7}{|l|}{ Gender } \\
\hline Male & 145 & 64.6 & 147 & 56.7 & & \\
\hline Female & 79 & 35.4 & 113 & 43.3 & 3.38 & 0.07 \\
\hline \multicolumn{7}{|l|}{ Hypertension } \\
\hline No & 106 & 47.4 & 176 & 67.5 & & \\
\hline Yes & 118 & 52.6 & 85 & 32.5 & 20.03 & $<0.001$ \\
\hline \multicolumn{7}{|l|}{ Diabetes mellitus } \\
\hline No & 152 & 67.7 & 232 & 89.3 & & \\
\hline Yes & 72 & 32.3 & 28 & 10.7 & 33.53 & $<0.001$ \\
\hline \multicolumn{7}{|l|}{ Alcohol drinking } \\
\hline Never & 108 & 48.37 & 136 & 52.3 & & \\
\hline Current or ever & 116 & 51.63 & 124 & 47.7 & 0.81 & 0.37 \\
\hline \multicolumn{7}{|l|}{ Tobacco smoking } \\
\hline Never & 97 & 43.1 & 175 & 67.4 & & \\
\hline Current or ever & 127 & 56.9 & 85 & 32.6 & 28.17 & $<0.001$ \\
\hline Body Mass Index, $\mathrm{kg} / \mathrm{m}^{2}$ & $24.61 \pm 4.16$ & & $21.57 \pm 3.64$ & & 11.39 & $<0.001$ \\
\hline $\mathrm{TC}, \mathrm{mg} / \mathrm{dL}$ & $195.25 \pm 41.52$ & & $167.40 \pm 32.65$ & & 8.25 & $<0.001$ \\
\hline LDL-c, $\mathrm{mg} / \mathrm{dL}$ & $116.30 \pm 25.36$ & & $99.43 \pm 25.76$ & & 7.24 & $<0.001$ \\
\hline HDL-c, $\mathrm{mg} / \mathrm{dL}$ & $39.42 \pm 20.44$ & & $44.63 \pm 11.42$ & & 3.52 & $<0.001$ \\
\hline $\mathrm{TG}, \mathrm{mg} / \mathrm{dL}$ & $132.56 \pm 42.53$ & & $113.26 \pm 26.30$ & & 6.09 & $<0.001$ \\
\hline
\end{tabular}

As confirmed by chi-square tests, CAD patients and control subjects differed significantly in genotype frequencies at $I L-6-174 \mathrm{G} / \mathrm{C}\left(\chi^{2}=10.85, \mathrm{P}=0.004\right)$, whereas no significant difference was observed between $I L-6-572 \mathrm{C} / \mathrm{G}$ genetic polymorphism and CAD risk (Table 2). In addition, genotype distributions of $I L-6-174 \mathrm{G} / \mathrm{C}$ were not in agreement with HWE in both groups, whereas those of $I L-6-572 \mathrm{C} / \mathrm{G}$ were in accordance with the HWE.

The relationship between $I L-6$ gene polymorphisms and development of CAD are summarized in Table 3. Using unconditional logistic regression analysis, we observed that the CC genotype at $I L-6-174 \mathrm{G} / \mathrm{C}$ was had a $2.32(95 \% \mathrm{CI}=1.33-4.06)$ fold risk of developing CAD compared to the GG genotype. Moreover, $I L-6-174 \mathrm{G} / \mathrm{C}$ polymorphism was positively associated with the risk of developing $\mathrm{CAD}$ in both dominant $(\mathrm{OR}=1.63,95 \% \mathrm{CI}=1.12-2.38$; $\mathrm{P}=0.01)$ and recessive models $(\mathrm{OR}=2.18,95 \% \mathrm{CI}=1.26-3.77 ; \mathrm{P}=0.001)$. However, no statistically significant association was observed between $I L-6-572 \mathrm{C} / \mathrm{G}$ polymorphism and risk of CAD in codominant, dominant, or recessive models.

Table 2. Genotype distributions of $I L-6-174 \mathrm{G} / \mathrm{C}$ and $-572 \mathrm{G} / \mathrm{C}$ gene polymorphisms between the two study groups.

\begin{tabular}{|c|c|c|c|c|c|c|c|c|}
\hline \multirow[t]{2}{*}{ IL-6 } & \multirow[t]{2}{*}{ Patients $(\mathrm{N}=224)$} & \multirow[t]{2}{*}{$\%$} & \multirow[t]{2}{*}{ Controls $(\mathrm{N}=360)$} & \multirow[t]{2}{*}{$\%$} & \multicolumn{2}{|c|}{$\mathrm{P}$ value for HWE } & \multirow[t]{2}{*}{$\chi^{2}$ test } & \multirow[t]{2}{*}{$\mathrm{P}$ value } \\
\hline & & & & & In cases & In controls & & \\
\hline \multicolumn{9}{|c|}{$-174 \mathrm{G} / \mathrm{C}$} \\
\hline GG & 142 & 63.39 & 267 & 74.17 & & & & \\
\hline $\mathrm{GC}$ & 45 & 20.09 & 63 & 17.50 & & & & \\
\hline $\mathrm{CC}$ & 37 & 16.52 & 30 & 8.33 & $<0.001$ & $<0.001$ & 10.85 & 0.004 \\
\hline \multicolumn{9}{|c|}{$-572 \mathrm{C} / \mathrm{G}$} \\
\hline $\mathrm{CC}$ & 97 & 43.30 & 147 & 40.83 & & & & \\
\hline CG & 110 & 49.11 & 176 & 48.89 & & & & \\
\hline GG & 17 & 7.59 & 37 & 10.28 & 0.06 & 0.14 & 1.28 & 0.53 \\
\hline
\end{tabular}

HWE $=$ Hardy-Weinberg equilibrium. 
Table 3. Relationship between $I L-6-174 \mathrm{G} / \mathrm{C}$ and $-572 \mathrm{G} / \mathrm{C}$ gene polymorphisms and development of CAD.

\begin{tabular}{|c|c|c|c|c|c|c|}
\hline IL-17 & Patients $(\mathrm{N}=224)$ & $\%$ & Controls $(\mathrm{N}=260)$ & $\%$ & OR $(95 \% \mathrm{CI})^{1}$ & P value \\
\hline \multicolumn{7}{|l|}{$-174 \mathrm{G} / \mathrm{C}$} \\
\hline \multicolumn{7}{|c|}{ Co-dominant } \\
\hline GG & 142 & 63.39 & 193 & 74.17 & 1.0 (Ref.) & - \\
\hline CG & 45 & 20.09 & 45 & 17.5 & $1.34(0.85-2.12)$ & 0.18 \\
\hline $\mathrm{CC}$ & 37 & 16.52 & 22 & 8.33 & $2.32(1.33-4.06)$ & $<0.001$ \\
\hline \multicolumn{7}{|l|}{ Dominant } \\
\hline GG & 142 & 63.39 & 193 & 74.17 & 1.0 (Ref.) & - \\
\hline $\mathrm{CG}+\mathrm{CC}$ & 82 & 36.61 & 67 & 25.83 & $1.63(1.12-2.38)$ & 0.01 \\
\hline \multicolumn{7}{|l|}{ Recessive } \\
\hline $\mathrm{GG}+\mathrm{CG}$ & 187 & 83.48 & 238 & 91.67 & 1.0 (Ref.) & - \\
\hline $\mathrm{CC}$ & 37 & 16.52 & 22 & 8.33 & $2.18(1.26-3.77)$ & 0.001 \\
\hline \multicolumn{7}{|l|}{$-572 \mathrm{G} / \mathrm{C}$} \\
\hline \multicolumn{7}{|c|}{ Co-dominant } \\
\hline $\mathrm{CC}$ & 81 & 36.3 & 106 & 40.83 & 1.0 (Ref.) & - \\
\hline GC & 110 & 49.11 & 127 & 48.89 & $1.12(0.75-1.68)$ & 0.56 \\
\hline GG & 33 & 14.59 & 27 & 10.28 & $1.60(0.86-2.95)$ & 0.11 \\
\hline \multicolumn{7}{|l|}{ Dominant } \\
\hline $\mathrm{CC}$ & 81 & 36.3 & 106 & 40.83 & 1.0 (Ref.) & - \\
\hline $\mathrm{GC}+\mathrm{GG}$ & 143 & 63.7 & 154 & 59.17 & $1.21(0.82-1.77)$ & 0.32 \\
\hline \multicolumn{7}{|l|}{ Recessive } \\
\hline $\mathrm{CC}+\mathrm{GC}$ & 191 & 85.41 & 233 & 89.72 & 1.0 (Ref.) & - \\
\hline GG & 33 & 14.59 & 27 & 10.28 & $1.50(0.85-2.63)$ & 0.13 \\
\hline
\end{tabular}

${ }^{1}$ Adjusted for age, gender, hypertension, diabetes mellitus, tobacco smoking, body mass index, TC, LDL-c, HDL-c, and TG.

\section{DISCUSSION}

In recent years, genomic susceptibility to diseases has attracted a growing attention to research the genetic polymorphisms involving in pathogenesis of diseases. The inflammatory status is an important step to keep and promote the pathogenesis of atherosclerosis. It is reported that the gene polymorphisms of inflammatory cytokine could affect cytokine mRNA transcription and thus change the serum levels of inflammatory cytokine (Larcombe et al., 2005). In the recent studies, emphasis often be focused on investigating the role of IL-6 polymorphisms to several kinds of diseases, such as chronic obstructive pulmonary disease, cardiovascular disease, HBV-related liver disease, or osteoporosis (Chang et al., 2015; Xie et al., 2015; Yan et al., 2015; Buraczynska et al., 2016). In our study, we carried out a study to investigate the role of $I L-6$ polymorphisms in the risk of CAD, and we revealed that the $I L-6$ $-174 \mathrm{G} / \mathrm{C}$ genomic polymorphism was correlated with an elevated risk to CAD in multiple genetic models.

Previous studies have shown that the $I L-6$ genomic variants is associated with IL-6 levels to the susceptibility to many diseases (Kiszel et al., 2006; Talar-Wojnarowska et al., 2009; Yeh et al., 2010). Talar-Wojnarowska et al. (2009) done a study with 97 pancreatic cancer or chronic pancreatitis patients and 50 healthy volunteers, and reported that IL-6 $-174 \mathrm{G} / \mathrm{C}$ gene polymorphism was correlated with circulating IL-6 levels and pathogenesis of pancreatic cancer. Yeh et al. (2010) carried out a study in Taiwanese, and revealed that $I L-6-174 \mathrm{G} / \mathrm{C}$ genomic variant could affect the expression and serum IL-6 and incidences of colorectal cancer. Therefore, the $I L-6$ genomic polymorphism may be associated with plasma level of $I L-6$ and thus influence the development of inflammation related diseases.

Although many studies assessed the relationship between $I L-6$ gene polymorphisms and pathogenesis of CAD, they reported conflicting results (Nauck et al., 2002; Vakili et al., 2011; Ghazouani et al., 2011; Phulukdaree et al., 2013; Satti et al., 2013; Elsaid et al., 2014; Sun et al., 2014; Wang et al., 2015). Three studies reported that the IL-6 -174 G allele 
was associated with higher mRNA expression levels of IL-6 and increased the risk of CAD (Vakili et al., 2011; Satti et al., 2013; Elsaid et al., 2014), whereas Phulukdaree et al. (2013) demonstrated that IL-6 -174 C allele could influence levels of IL-6 and increased the risk of CAD. Two studies carried out studies in Chinese population, and reported that IL-6 -174G/C genomic polymorphisms could influence the risk of CAD (Sun et al., 2014; Wang et al., 2015). However, Nauck et al. (2002) and Ghazouani et al. (2011) reported that IL-6 -174G/C had not significantly correlation with CAD risk. In our study, we revealed that $I L-6-174 \mathrm{G} / \mathrm{C}$ genomic variation was correlated with a higher risk of CAD. The discrepancies between our results and those of studies may be due to differences in study populations, experimental designs, and sample size.

In conclusion, based on our results, we suggest that $I L-6-174 \mathrm{G} / \mathrm{C}$ polymorphisms are associated with the pathogenesis of CAD. Further studies are needed to elucidate the impact of $I L-6$ genomic polymorphisms in the risk of CAD.

\section{Conflicts of interest}

The authors declare no conflicts of interest.

\section{ACKNOWLEDGMENTS}

We thank for staffs in Henan Provincial People's Hospital, and these staffs help us to collect blood samples from patients.

\section{REFERENCES}

Buraczynska M, Zukowski P, Drop B, Baranowicz-Gaszczyk I, et al. (2016). Effect of G(-174)C polymorphism in interleukin-6 gene on cardiovascular disease in type 2 diabetes patients. Cytokine 79: 7-11. http://dx.doi.org/10.1016/j. cyto.2015.12.004

Chang L, Lan T, Wu L, Li C, et al. (2015). The association between three IL-6 polymorphisms and HBV-related liver diseases: a meta-analysis. Int. J. Clin. Exp. Med. 8: 17036-17045.

de Albuquerque Maranhão RM, Martins Esteves FA, Crovella S, Segat L, et al. (2015). Tumor necrosis factor-a and interleukin-6 gene polymorphism association with susceptibility to celiac disease in Italian patients. Genet. Mol. Res. 14: 16343-16352. http://dx.doi.org/10.4238/2015.December.9.2

Dhar S, Chatterjee S, Ray S, Dutta A, et al. (2010). Polymorphisms of methylenetetrahydrofolate reductase gene as the genetic predispositions of coronary artery diseases in eastern India. J. Cardiovasc. Dis. Res. 1: 152-157. http://dx.doi. org/10.4103/0975-3583.70922

Elsaid A, Abdel-Aziz AF, Elmougy R and Elwaseef AM (2014). Association of polymorphisms G(-174)C in IL-6 gene and G(-1082)A in IL-10 gene with traditional cardiovascular risk factors in patients with coronary artery disease. Indian J. Biochem. Biophys. 51: 282-292.

Fernandes MT, Fernandes KB, Marquez AS, Cólus IM, et al. (2015). Association of interleukin-6 gene polymorphism (rs1800796) with severity and functional status of osteoarthritis in elderly individuals. Cytokine 75: 316-320. http:// dx.doi.org/10.1016/j.cyto.2015.07.020

Han H, Wang H, Yin Z, Jiang H, et al. (2013). Association of genetic polymorphisms in ADH and ALDH2 with risk of coronary artery disease and myocardial infarction: a meta-analysis. Gene 526: 134-141. http://dx.doi.org/10.1016/j. gene.2013.05.002

He J, Gu D, Wu X, Reynolds K, et al. (2005). Major causes of death among men and women in China. N. Engl. J. Med. 353: 1124-1134. http://dx.doi.org/10.1056/NEJMsa050467

Kiszel P, Fust G, Pessi T, Hurme M, et al. (2006). Associations between interleukin-6 genetic polymorphisms and levels of autoantibodies to 60-kDa heat-shock proteins. Hum. Hered. 62: 77-83. http://dx.doi.org/10.1159/000096095

Ghazouani L, Abboud N, Ben Hadj Khalifa S, Added F, et al. (2011). -174G $>$ C interleukin-6 gene polymorphism in 
Tunisian patients with coronary artery disease. Ann. Saudi Med. 31: 40-44. http://dx.doi.org/10.4103/0256$\underline{4947.75777}$

Go AS, Mozaffarian D, Roger VL, Benjamin EJ, et al.; American Heart Association Statistics Committee and Stroke Statistics Subcommittee (2014). Heart disease and stroke statistics - 2014 update: a report from the American Heart Association. Circulation 129: e28-e292. http://dx.doi.org/10.1161/01.cir.0000441139.02102.80

Larcombe L, Rempel JD, Dembinski I, Tinckam K, et al. (2005). Differential cytokine genotype frequencies among Canadian Aboriginal and Caucasian populations. Genes Immun. 6: 140-144. http://dx.doi.org/10.1038/sj.gene.6364157

Li L, Li E, Zhang LH, Jian LG, et al. (2015). IL-6-174G/C and IL-6-572C/G polymorphisms are associated with increased risk of coronary artery disease. Genet. Mol. Res. 14: 8451-8457. http://dx.doi.org/10.4238/2015.July.28.12

Liu SL, Yin YW, Sun QQ, Hu AM, et al. (2015). Genetic polymorphisms of interleukin-6 gene and susceptibility to coronary artery disease in Chinese population: Evidence based on 4582 subjects. Hum. Immunol. 76: 505-510. http:// dx.doi.org/10.1016/j.humimm.2015.06.004

Marenberg ME, Risch N, Berkman LF, Floderus B, et al. (1994). Genetic susceptibility to death from coronary heart disease in a study of twins. N. Engl. J. Med. 330: 1041-1046. http://dx.doi.org/10.1056/NEJM199404143301503

Nauck M, Winkelmann BR, Hoffmann MM, Böhm BO, et al. (2002). The interleukin-6 G(-174)C promoter polymorphism in the LURIC cohort: no association with plasma interleukin-6, coronary artery disease, and myocardial infarction. $J$. Mol. Med. 80: 507-513. http://dx.doi.org/10.1007/s00109-002-0354-2

Phulukdaree A, Khan S, Ramkaran P, Govender R, et al. (2013). The interleukin-6 -147 g/c polymorphism is associated with increased risk of coronary artery disease in young South African Indian men. Metab. Syndr. Relat. Disord. 11: 205-209. http://dx.doi.org/10.1089/met.2012.0130

Ramos Dos Santos L, Belcavello L, Camporez D, Iamonde Maciel de Magalhães C, et al. (2016). Association study of the BIN1 and IL-6 genes on Alzheimer's disease. Neurosci. Lett. 614: 65-69. http://dx.doi.org/10.1016/j. $\underline{\text { neulet.2015.12.046 }}$

Ross R (1999). Atherosclerosis--an inflammatory disease. N. Engl. J. Med. 340: 115-126. http://dx.doi.org/10.1056/ NEJM199901143400207

Satti HS, Hussain S and Javed Q (2013). Association of interleukin-6 gene promoter polymorphism with coronary artery disease in Pakistani families. ScientificWorldJournal 2013: 538365. http://dx.doi.org/10.1155/2013/538365

Sun GQ, Wu GD, Meng Y, Du B, et al. (2014). IL-6 gene promoter polymorphisms and risk of coronary artery disease in a Chinese population. Genet. Mol. Res. 13: 7718-7724. http://dx.doi.org/10.4238/2014.September.26.9

Talar-Wojnarowska R, Gasiorowska A, Smolarz B, Romanowicz-Makowska H, et al. (2009). Clinical significance of interleukin-6 (IL-6) gene polymorphism and IL-6 serum level in pancreatic adenocarcinoma and chronic pancreatitis. Dig. Dis. Sci. 54: 683-689. http://dx.doi.org/10.1007/s10620-008-0390-z

Tousoulis D, Koumallos N, Antoniades C, Antonopoulos AS, et al. (2010). Genetic polymorphism on type 2 receptor of angiotensin II, modifies cardiovascular risk and systemic inflammation in hypertensive males. Am. J. Hypertens. 23: 237-242. http://dx.doi.org/10.1038/ajh.2009.233

Vakili H, Ghaderian SM, Akbarzadeh Najar R, Tabatabaei Panah AS, et al. (2011). Genetic polymorphism of interleukin-6 gene and susceptibility to acute myocardial infarction. Coron. Artery Dis. 22: 299-305. http://dx.doi.org/10.1097/ MCA.0b013e $328346 \mathrm{~b} 848$

Wang K, Dong PS, Zhang HF, Li ZJ, et al. (2015). Role of interleukin-6 gene polymorphisms in the risk of coronary artery disease. Genet. Mol. Res. 14: 3177-3183. http://dx.doi.org/10.4238/2015.April.10.29

Wilson PW, D'Agostino RB, Levy D, Belanger AM, et al. (1998). Prediction of coronary heart disease using risk factor categories. Circulation 97: 1837-1847. http://dx.doi.org/10.1161/01.CIR.97.18.1837

Xie XM, Ke R, Zhang YH, Wang GZ, et al. (2015). Interleukin-6 gene -174G $>$ C polymorphism and chronic obstructive pulmonary disease risk: a meta-analysis. Genet. Mol. Res. 14: 8516-8525. http://dx.doi.org/10.4238/2015.July.28.21

Xu F, Chen Y, Lv R, Zhang H, et al. (2010). ALDH2 genetic polymorphism and the risk of type II diabetes mellitus in CAD patients. Hypertens. Res. 33: 49-55. http://dx.doi.org/10.1038/hr.2009.178

Yan L, Hu R, Tu S, Cheng WJ, et al. (2015). Meta-analysis of association between IL-6 -634C/G polymorphism and osteoporosis. Genet. Mol. Res. 14: 19225-19232. http://dx.doi.org/10.4238/2015.December.29.32

Yang HT, Wang SL, Yan LJ, Qian P, et al. (2015). Association of interleukin gene polymorphisms with the risk of coronary artery disease. Genet. Mol. Res. 14: 12489-12496. http://dx.doi.org/10.4238/2015.October.16.16

Yeh KY, Li YY, Hsieh LL, Chen JR, et al. (2010). The -174 G/C polymorphism in interleukin-6 (IL-6) promoter region is associated with serum IL-6 and carcinoembryonic antigen levels in patients with colorectal cancers in Taiwan. $J$. Clin. Immunol. 30: 53-59. http://dx.doi.org/10.1007/s10875-009-9324-6 